\title{
WORKSPACE SUPERVISING SYSTEM FOR MATERIAL HANDLING DEVICES WITH MACHINE VISION ASSISTANCE
}

\section{SYSTEM NADZOROWANIA PRZESTRZENI ROBOCZEJ ŚRODKOW TRANSPORTU BLISKIEGO Z WYKORZYSTANIEM TECHNIKI WIDZENIA MASZYNOWEGO}

\author{
Janusz Szpytko, Paweł Hyla \\ AGH University of Science and Technology, \\ Ave. A. Mickiewicza 30, PL 30-059 Kraków, Poland, \\ E-mail:szpytko@agh.edu.pl_hyla@agh.edu.pl
}

\begin{abstract}
The paper is focus on the possibility of the implementation machine vision system for the purposes supervising the transport device workspace interface including operation safety needs. The object of statement is structure of automatic supervising system built on the base material handling devices with open kinematic chain of the Cartesian type based on one CCD device.
\end{abstract}

Keywords: 3D reconstruction, laser scanning system, machine vision

Streszczenie: Artykuł jest zorientowany na możliwości implementacji sytemu widzenia maszynowego w zakresie automatycznego interfejsu nadzorowania przestrzeni roboczej środka transportu $\mathrm{z}$ uwzględnieniem potrzeb $\mathrm{w}$ zakresie bezpieczeństwa procesów użytkowania. Przedmiotem jest budowa systemu jednokamerowego dla celów nadzorowania przestrzeni roboczej środka transportu przemysłowego z prostokątnym układem współrzędnych i prostopadłościenną przestrzenią ruchu.

Słowa kluczowe: odtwarzanie 3D, system skanowania laserowego, widzenie maszynowe 


\section{Introduction}

Visual perception delivers to the human being more than $80 \%$ [4] information about the environment. The growth of visual information in our surroundings has raised a demand for effective acquire and processing visual information. Human Visual System has developed in course of millions of years of natural evolution and near a half of our cerebral cortex is busy with processing visual information. On the base human HVS, vision engineers trying gain answers how to attached vision possibility to the machines.

First set of vision systems only supporting interactions between the M-MS through clean video stream. This type of system is not very effective because operator can works effectively with vision stream only in two hour long cycle with four video display showing the image at the same time [18]. Today majority semi-automatic vision systems is supported by the continually improvement image processing technique. The main result of this change is vision systems efficiency growth. Technical progress delivers new class of vision system so-called machine vision. This technology use smart cameras as a main vision system unit. Smart camera is a vision system that not only takes images, but also understands them. Smart camera is defined as a vision system [2] which, in addition to image capture circuitry, is capable of extracting application-specific information from the captured images, along with generating event descriptions or making decisions that are used in an intelligent and automated system.

\section{Methods for three-dimensional video imaging}

One of the primary areas in three-dimensional video imaging is a recovery of $3 \mathrm{D}$ information about the shape of object in the video scene, using known vision analysis methods. The widely known stereo vision methods are vision systems obtaining 3D information consist identification of two corresponding 2D points between left and right side of the image of the scene (Fig.1.). 


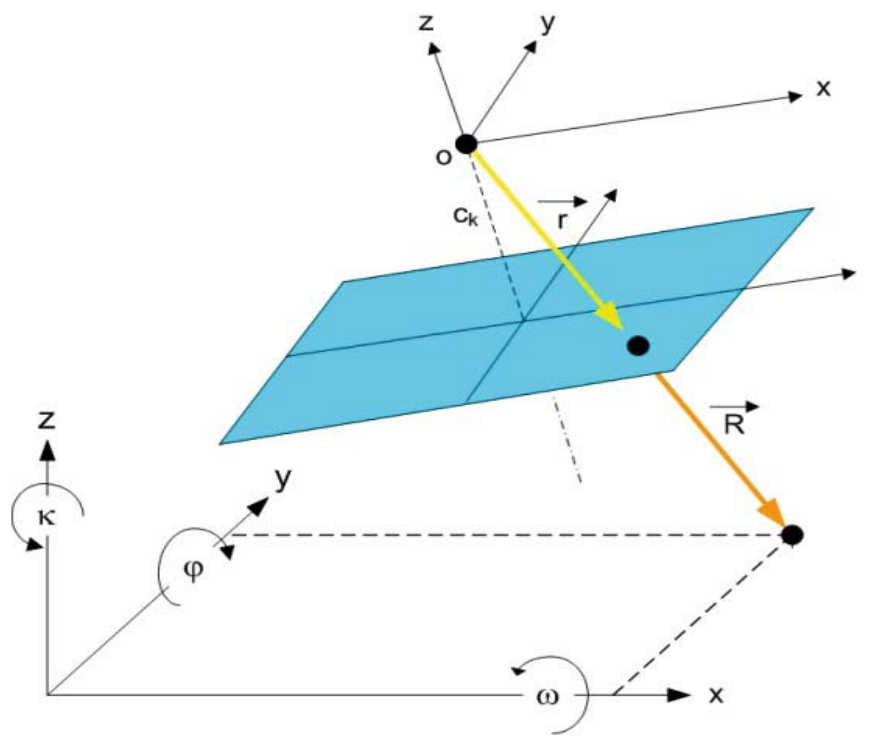

Fig.1. Two collinear vector: vector radius of image space $\bar{R}$ and vector of objective space $\vec{r}$

Coordinates of the point in reference frame are determinate agreeably with rule that the projected vector radius in image space of the camera lens is collinear with vector in objective space. Vector radius of image space (1) and vector in objective space (2) can be reduce to one system: equation (3) and (4), where A is a transformation matrix (5).

$$
\begin{aligned}
& \vec{R}=\lambda \vec{r} \\
& r=\frac{1}{\bar{J}} \cdot \bar{R} \\
& {\left[\begin{array}{c}
x-X_{0} \\
y-Y_{0} \\
z-Z_{0}
\end{array}\right]=A \cdot A\left[\begin{array}{c}
x \\
y \\
-c_{k}
\end{array}\right]} \\
& {\left[\begin{array}{c}
x \\
y \\
-c_{k}
\end{array}\right]=\frac{1}{\lambda} \cdot A^{T}\left[\begin{array}{c}
X-X_{0} \\
Y-Y_{2} \\
Z-Z_{0}
\end{array}\right]} \\
& A=\left[\begin{array}{ccc}
\cos \varphi \cos \alpha & -\cos \varphi \sin \alpha & \sin \varphi \\
\cos \omega \sin \alpha+\sin \omega \sin \varphi \cos \alpha & \cos \omega \cos \alpha-\sin \omega \sin \varphi \sin \alpha & -\sin \omega \cos \varphi \\
\sin \omega \sin \alpha+\cos \omega \sin \varphi \cos \alpha & \sin \omega \cos \alpha+\cos \omega \sin \varphi \sin \alpha & \cos \omega \cos \varphi
\end{array}\right]
\end{aligned}
$$


where: A - orthogonal matrix of transformation,

$\omega$ - vertical axis inclination (plane YZ),

$\varphi$ - vertical axis inclination (plane XZ),

$\kappa$ - image rotation (plane $X Y$ ),

$c_{k}$ - constant distance,

$\lambda$ - ratio between $|\mathrm{R}|:|\mathrm{r}|$,

$X_{0}, Y_{0}, Z_{0}$-coordinates of central projection in reference frame.

However this is not enough, because projected radius, reconstructed with the help of presented equation carried too small information about point coordinates in the space (Fig.2).

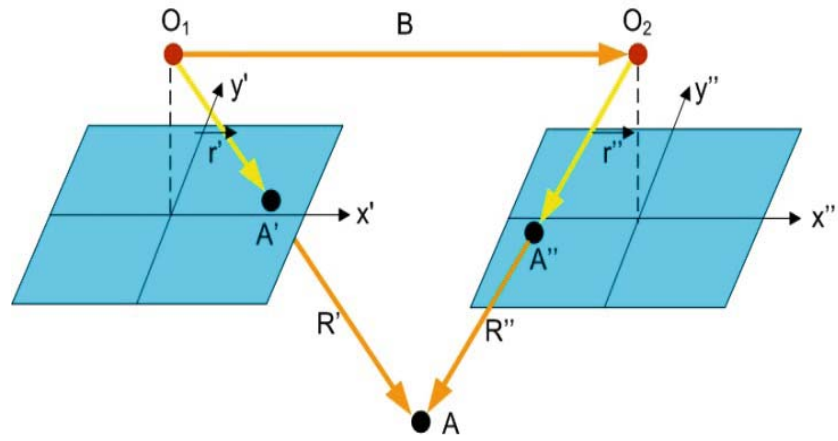

Fig.2. Point coordination on the base of two planes view.

In the Fig. 2, we can observed that vector linking both means of parts (base vector) and projective vectors to the $A$ point are coplanar. This condition is met, when the mixed product of these vectors is equal zero (6).

$$
\vec{B} \cdot\left(\overrightarrow{R^{\prime}} \times \overrightarrow{R^{\prime \prime}}\right)=0
$$

In practical solution it is possible to use images from two cameras, because two collinear vectors give six equation with only five unknown quantity: $X$, $\mathrm{Y}, \mathrm{Z}$ and ratio scale $\lambda^{\prime}$ and $\lambda$ '”.

\section{3D Geometry of an object from images acquired with a single-camera - literature review.}

A number of different methods for obtaining a 3D geometry with use multiples cameras is very rich. One of the most popular and oldest method is DLT (Direct Linear Transformation) transformation [1] but use two [8], three [17] or more cameras often are impractical or too costly. 
The first described a single-camera 3D application was publish in 1930 [3]. In reference [7] author decrypted used method, based mainly on a mirror solution. This mirror gave a second view of the object. Information about second view of the object was saved together with mother image. In another year scientist and engineers try find technique useful to extract 3D information from 2D images. Today we known that is impossible to determinate the $3 \mathrm{D}$ position of a lone marker in space with help of $2 \mathrm{D}$ image acquired with one camera (in static mode). One camera can be used to determinate positions of a single or multiple markers in on the object in space, establishing that we known distance between this markers. Markers can be use as a strip (Fig.3), laser matrix (Fig.4) or simply stickers (Fig.5.)

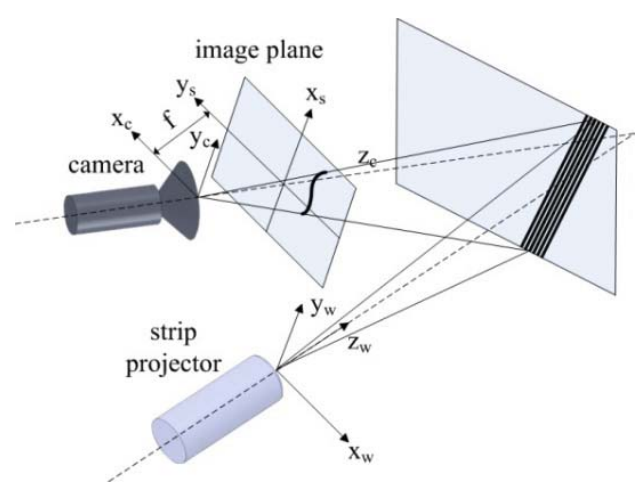

Fig.3. 3D information from 2D image: strip projector [10]

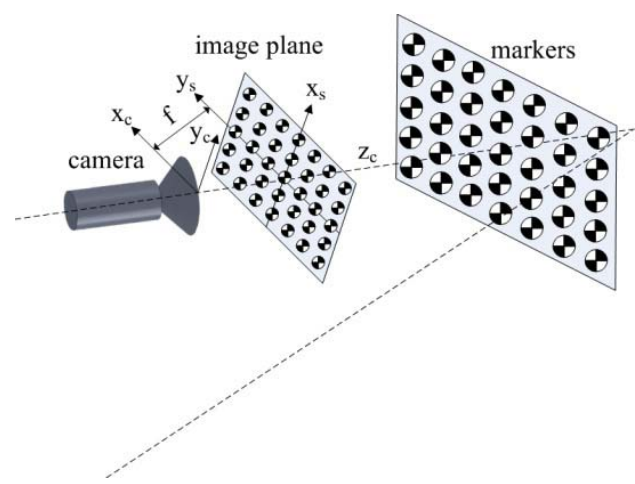

Fig.5. 3D information from 2D image: markers on the object [7]

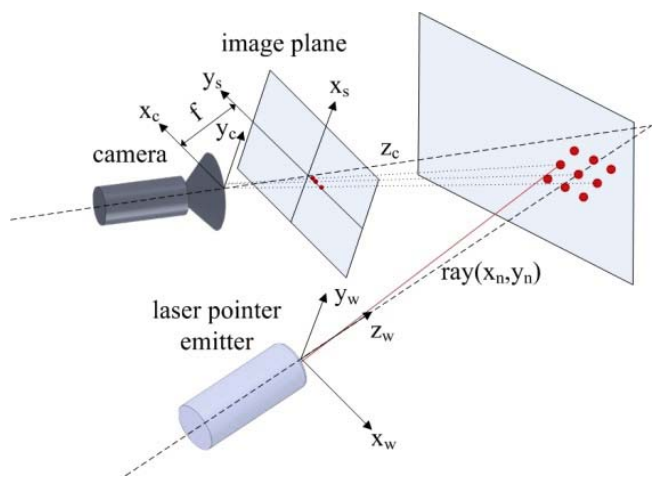

Fig.4. 3D information from 2D image: laser matrix projector $[5,6]$

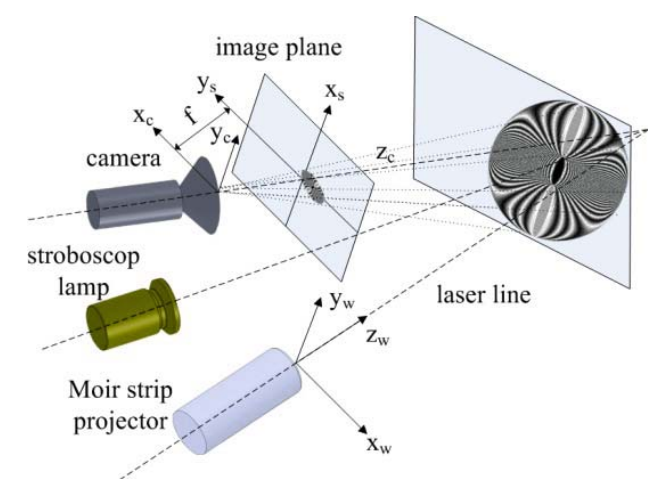

Fig.6. 3D information from 2D image: Moiré strip \& stroboscope effect [14]

On the Fig.6 was presented a very interesting scanning system use one camera. This 2-D Moiré pattern projection system with Fast Fourier 
transform (FFT) can be use to scanning revolving object through stroboscope effect.

\section{Laboratory double girder crane work space telematics inspection system}

The automatic control and steering of transport device foster to develop methods and tools for supervising the workspace of transport device [16]. Recording the workspace of transport devices enable to mark out the optimum grade-separated trajectory of transferring cargo. In order to solve discussed issues for the transport device was designed a novel conception for mapping the workspace.

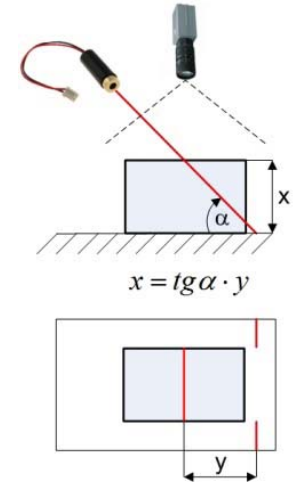

Fig.7. 3D information from 2D image: laser line emitter

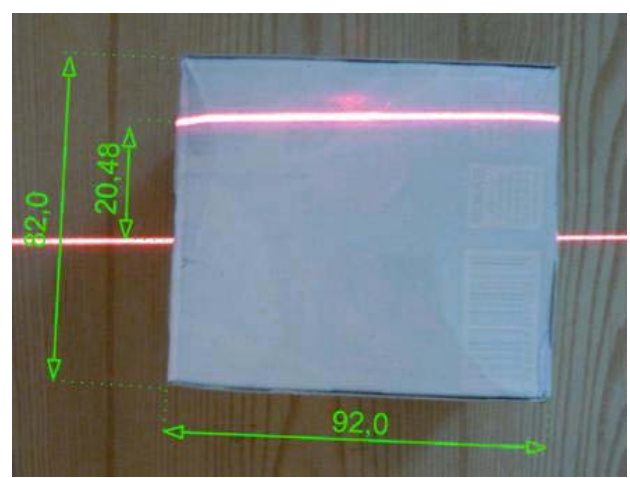

Fig.8. Machine vision measuring system

The rectangular element height is poses with using the laser line emitter and smart camera (hardware) and a machine vision system (software) [13]. This measuring system implementing for inspection laboratory double girder crane work space give appoint possibility of design a optimum trajectory for transferring a cargo. 


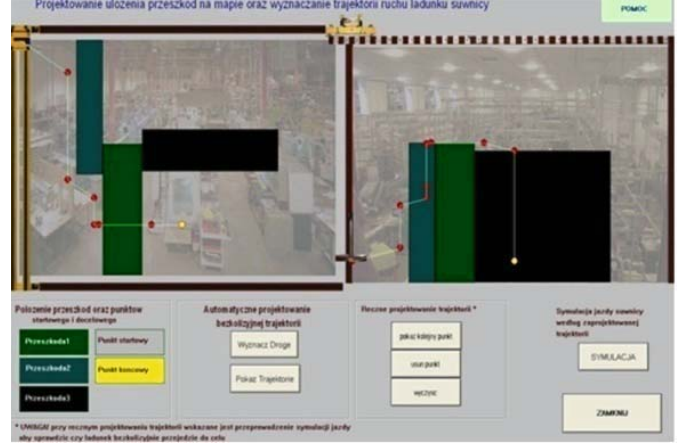

Fig.9. Material handling space work visualization in SCAD software

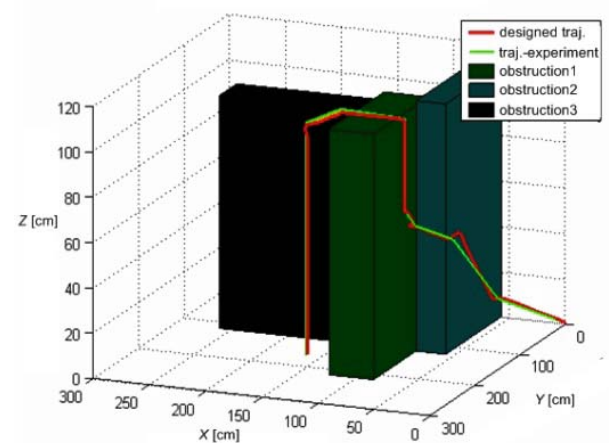

Fig.10. Designed trajectory visualization [12]

4.1 Off-line work space inspection system

The system of supervising the work space in the off-line mode can only copy the workspace and gather information about the potential obstacle. The restrictions associated with the time run of the measurement eliminating this system type in complex transport system with different classes devices.

\subsection{On-line work space inspection system}

In the on-line arrangement, the system of supervising, monitor the workspace during work movements. Providing the uninterrupted stream of the information concerning obstacles in a workspace enabling to outline the grade-separated trajectory requires abilities of the automatic reconfiguration of the system. Including the speed change of the crane bridge, the system working in the online mode must have possibility change range of angle the laser line emitter. It is necessary to get indispensable zone (Fig.11) to obtain calculation and make virtual workspace for needs of the simulation. One of the crucial restrictions are crane bridge mechanism speeds (Table 1)

Tab. 1. Overhead cranes girder- bridge speeds [9]

\begin{tabular}{|l|c|c|c|c|c|c|c|c|}
\hline$[\mathrm{m} / \mathrm{min}]$ & 20 & 25 & 31,5 & 40 & 50 & 63 & 80 & 100 \\
\hline$[\mathrm{mm} / \mathrm{s}]$ & 333,3 & 416,667 & 525 & 666,667 & 833,3 & 1050 & 1333,3 & 1666,67 \\
\hline
\end{tabular}




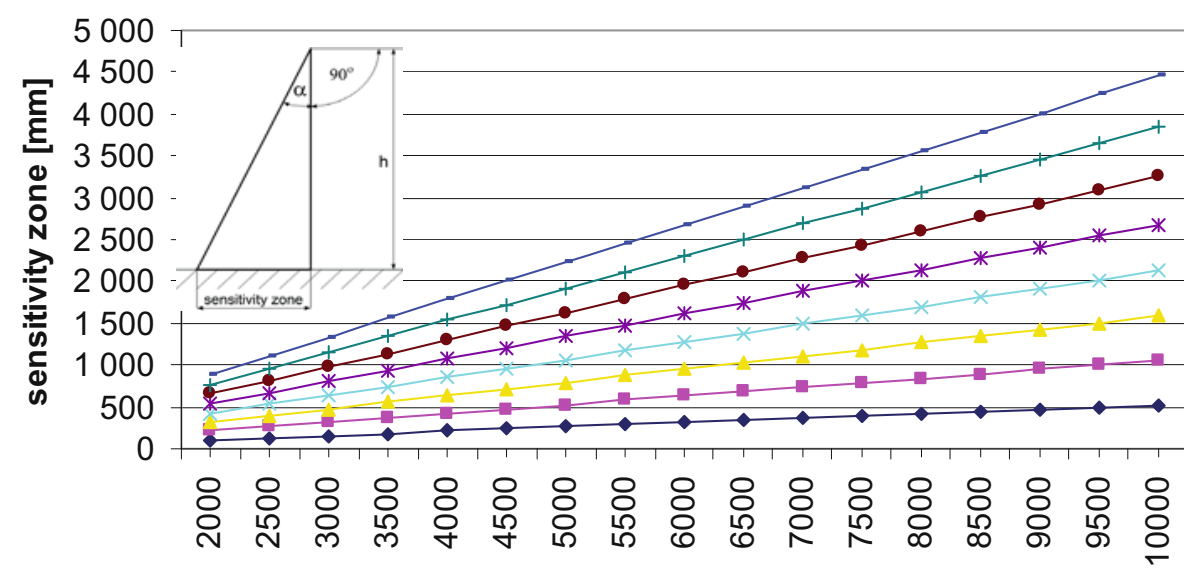

$\mathrm{h}[\mathrm{mm}]$

$\alpha\left[^{\circ}\right] \multimap 3-6-6 \div 9 \div 12 \div 15 \rightarrow 18 \div 21-24$

Fig.11. Sensitivity zone in laser line angle function

\section{Conclusions}

Fundamental advantage of the presented machine vision system designed for transport device workspace supervising is a simply architecture of this system. However, the present vision system is a full machine vision with all gain of this type system [11].

The utilities of the used method are its low-cost, safety operation devices oriented, simplicity, and ease of implementation. This method may be useful in pilot studies, because it is a good alternative to multi-camera systems.

The research project is financed from the Polish Science budget for the year 2008-12.

\section{References}

[1] Abdel-Aziz Y.I., Karara H.M.: Direct linear transformation from comparator coordinates into object space coordinates in close-range photogrammetry. In: Proceedings ASP/UI Symposium on Close-Range Photogrammetry, American Society of Photogrammetry, Falls Church, VA, pp.1-18, 1971.

[2] Belbachir A.N. (Ed.): Smart Cameras. Springer, 2009. 
[3] Berstein N.: Untersuching der Korperbewegungen and Korperstellungen im Raum mittens Spugelaufnahmen. Arbeitsphysiologie, Vol. 3, pp.330, 1930.

[4] Diamant E.: Lecture Notes in Computer Science, Vol. 4729, pp.62-71, Springer, Berlin/Heidelberg 2007.

[5] Dipanda A., Woo S., Marzani F., Bilbault J.M.: 3-D shape reconstruction in an active stereo vision system using genetic algorithms. Pattern Recognition, Vol. 36, pp.2143-2159, 2003.

[6] Dipanda A., Woo S.: Towards a real-time 3D shape reconstruction using a structured light system. Pattern Recognition, Vol. 38, pp.1632-1650, 2005.

[7] Eian J. , Poppele R.E.: A single-camera method for three-dimensional video imaging. Journal of Neuroscience Methods, Vol. 120, pp.65-83, 2002.

[8] Lanea Ch., Harrell W.: Completing the 3-dimensional picture. American Journal of Orthodontics and Dentofacial Orthopedics. Vol. 133, No. 4, pp.612-620, 2008.

[9] Latek W.(red), Moroz W.(red): Poradnik inżyniera elektryka. Tom 2, WNT, Warszawa, 1975.

[10] Rychlik M.: Skanery 3D - wrota do wirtualnego świata. DESIGN NEWS Polska, str.36-40, kwiecień 2007.

[11] Smith M.L, Smith L.N.: Special issue on Machine Vision. Computers in Industry, Vol. 56, pp.773-776, 2005.

[12] Smoczek J., Szpytko J.: Zastosowanie algorytmów heurystycznych $w$ systemach sterowania ruchem suwnic. Materiały XXII Konferencji Naukowej Problemy Rozwoju Maszyn Roboczych, CD ROM, Zakopane 2009.

[13] STEAMER IMAGING: Getting started guide: First steps with Common Vision Blox. Puchheim, 2008.

[14] Su X., Zhang Q.: Dynamic 3-D shape measurement method: A review. Optics and Lasers in Engineering. Article in press, Elsevier, 2009.

[15] Szpytko J., Hyla P.: Reverse engineering vision technique applying in transport systems. Journal of KONES Powertrain and Transport, Vol. 16, No. 3, pp.395-400, Warsaw 2009.

[16] Yamauchi R., Ikeda M., Shinoda H.: Walls surrounding a space work more efficiently construct a recognized visual space of illumination than do scattered objects. Optical Review, Vol. 10, No. 3, pp.166-173, 2003.

[17] Yasushi S., Yutaka I., Fumiaki T.: Robot-vision architecture for realtime 6-DOF object localization. Computer Vision and Image Understanding, Vol. 105, pp.218-230, 2007. 
[18] Życzkowski M., Szustakowski M., Wróbel J.: Nowe technologie w ochronie infrastruktury krytycznej. Instytut Optoelektroniki, Wojskowa Akademia Techniczna, Warszawa, 2008.

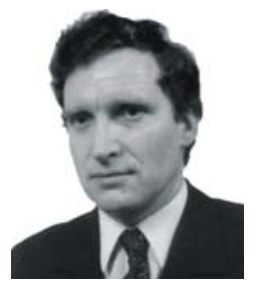

Prof. dr hab. Inż. Janusz SZPYTKO, AGH University of Science and Technology, Faculty of Mechanical Engineering and Robo-tics. Specialist in designing and exploitation of transport systems and devices, automatics, safety and reliability, monitoring and diagnostics, decision making systems, telematics. Author or co-author of more then 300 publications, both in Polish and English. Member of: STST KT PAN, TC IFAC, SEFI, ISPE, PTD, PTB, PSRA, ISA, SITPH and others. Visiting professor at the universities in: UK, France, Canada, Italy, Greece, Canada, Laos. Coordinator and member of several $R \& D$ projects both national and international. Organizer and member of several scientific and programme committees of international and national conferences and symposiums

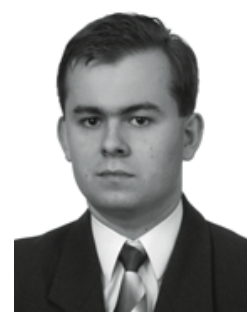

Mgr inż. Pawel HYLA, AGH University of Science and Technology, Faculty of Mechanical Engineering and Robotics. Specialization: engineering, GPS technology, object tracking, telematics. Several publications in field. 